\title{
THE FORMATION OF INTERSTATE AND CROSS-BORDER SCIENTIFIC- EDUCATIONAL AND INNOVATIVE SPACES BETWEEN UKRAINE AND THE EUROPEAN UNION MEMBER STATES IN THE DIGITAL ECONOMY
}

\author{
Viacheslav Lyashenko and Iryna Pidorycheva
}

\begin{abstract}
By signing the Association Agreement between the EU and Ukraine, Ukraine has demonstrated its intention and willingness to integrate into the system of formal institutions of the EU, to adopt the EU rules, norms, and practices, which will enable Ukraine to achieve significant economic benefits. One of those benefits is the opportunity to build a true scientific-educational and innovative partnership with the EU Member States within the European Research Area. This study considers opportunities and perspectives of creating an interstate and cross-border scientificeducational and innovative spaces between Ukraine as an associated country and the European Union Member States taking into account key priorities of the ERA and rapidly growing impact of digital technologies. Particular attention has been given to the establishment of a common PolishUkrainian scientific-educational space which could be complemented by the entrepreneurial component. The article has identified opportunities, existing prerequisites, directions, and priorities for building Polish-Ukrainian spaces. It has also defined the challenges of formation the European interstate and cross-border scientific-educational and innovative spaces as a whole. It has been suggested to develop hereinafter an interstate and cross-border high-tech clusters based on the interstate and cross-border scientific-educational and innovative spaces. The scheme and the main steps of formation a cross-border cluster of nano- and biotechnologies are proposed.

Keywords: scientific-educational and innovative spaces, digital economy, the Fourth Industrial Revolution, the European Research Area, digital technologies, high-technology cluster
\end{abstract}

JEL Classification: F2, F5, O31, 033

\section{Author(s):}

\section{Viacheslav Lyashenko}

The Institute of Industrial Economics of the National Academy of Sciences of Ukraine, 2, Zhelyabova Street, Kyiv, Ukraine, 03057

E-mail: slaval.aenu@gmail.com, https://orcid.org/0000-0001-6302-0605

Iryna Pidorycheva

The Institute of Industrial Economics of the National Academy of Sciences of Ukraine, 2, Zhelyabova Street, Kyiv, Ukraine, 03057

E-mail: pidoricheva@nas.gov.ua, https://orcid.org/0000-0002-4622-8997,

Citation: Lyashenko, V., \& Pidorycheva, I. (2019). The formation of interstate and cross-border scientificeducational and innovative spaces between Ukraine and the European Union member states in the digital economy. Virtual Economics, 2(2), 48-58. https://doi.org/10.34021/ve.2019.02.02(3)

Received: January 7, 2019,. Revised: February 21, 2019. Accepted: March 10, 2019.

(C) Author(s) 2019. Licensed under the Creative Commons License - Attribution 4.0 International (CC BY 4.0) 


\section{Introduction}

The main source of economic growth and industrial development for developing countries is their absorptive capacity, or ability to tap into the world knowledge and technology. This is evidenced by the report of the World Bank as part of a series undertaken by the Europe and Central Asia Region (Goldberg et al., 2011). The authors of this research report highlight that the process of knowledge and technology absorption is neither automatic nor costless. Rather, this process requires extensive, active efforts, particularly - "dense links to the global knowledge economy, human capital, and a learning-by-doing process, among other factors". The main "channels of absorption" are foreign direct investment (FDI), trade, human capital and mobility, research and development, and flows of codified knowledge (patents, standards, and publications) Fig. 1 (Goldberg et al., 2011).

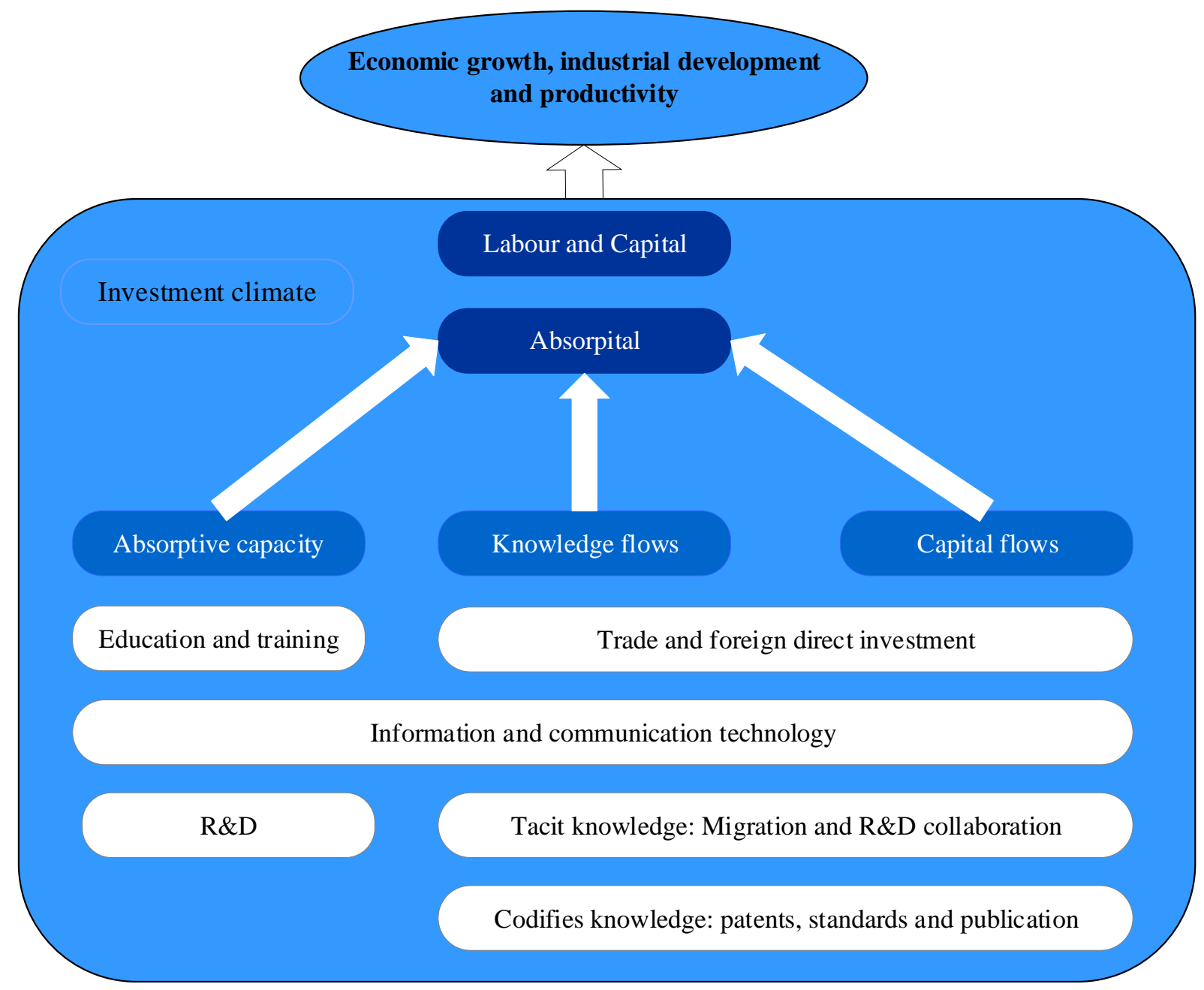

Figure 1. "Channels of absorption" of knowledge and technology that spur economic growth, industrial development and productivity

Source: (Goldberg et al, 2011). 
The availability of effective institutions and dynamic local firms are main conditions for taking advantage of these "channels of absorption," hence the importance of regional level in world economic processes. The OECD study found that the most intensive interactions between economic agents take place within a radius of approximately $200 \mathrm{~km}$ (The Organization for Economic Co-operation and Development, 2013).

By signing the Association Agreement between the European Union (EU) and the European Atomic Energy Community and their Member States, as one party, and Ukraine, as the other party, (hereinafter referred to as Association Agreement between the EU and Ukraine), Ukraine has demonstrated its intention and willingness to integrate into the system of formal institutions of the EU, to adopt the EU rules, norms, and practices, which will enable Ukraine to achieve significant economic benefits. One of those benefits is the opportunity to build a true scientific-educational and innovative partnership with the EU Member States within the European Research Area (ERA) using the above-mentioned "channels of absorption."

In our opinion, such a process, on the one hand, needs to be considered according to regional specificity as each region is unique and has its competitive advantages and weaknesses that determine its path of development, directions, and priorities of integration into European spaces. On the other hand, the conditions of the digital economy that will fundamentally transform human lives, activities of companies and governments in the near future should be taken into account.

\section{Literature Review}

Contemporary science is looking for the answers to the unprecedented depth and severity of socio-economic transformations that engulfed the modern world, to the challenges of increasing competition on world markets, to the objective processes of globalization and the growing importance of regional factors in the production of knowledge and turning them into innovation (Dźwigoł et al., 2019; Dźwigoł and Dźwigoł-Barosz, 2018).

According to Philip Cooke, globalization of markets has significantly changed the competitive conditions for most companies that compete on time, price and quality. As a result, they should change their business organization, consumer and supplier relationships to be competitive. But in so doing, companies will be more successful in the global economy if they join their efforts in local (regional) environment (Cooke, 2001). Klaus Schwab considers regions and cities as centers of innovation networks, which will be important for the competitiveness of countries at a time of digital revolution (Schwab, 2015).

In view of the rapidly growing fourth industrial revolution, many countries and regions are in a difficult situation of transition from a purely industrial specialization, that prevailed in XX century, to the economy in which key technologies play the leading role. The World Economic Forum (2018a) Report provides a list and a description of twelve key emerging technologies of the fourth industrial revolution Table 1. 
Table 1. Twelve key emerging technologies of the fourth industrial revolution

\begin{tabular}{|c|c|}
\hline Technology & Description \\
\hline $\begin{array}{l}\text { Artificial intelligence and } \\
\text { robotics }\end{array}$ & $\begin{array}{l}\text { Development of machines that can substitute for humans, increasingly in } \\
\text { tasks associated with thinking, multitasking and fine motor skills }\end{array}$ \\
\hline Ubiquitous linked sensors & $\begin{array}{l}\text { Also known as the "Internet of Things." The use of networked sensors to } \\
\text { remotely connect, track and manage products, systems and grids }\end{array}$ \\
\hline $\begin{array}{l}\text { Virtual and augmented } \\
\text { realities }\end{array}$ & $\begin{array}{l}\text { Next-step interfaces between humans and computers involving } \\
\text { immersive environments, holographic readouts and digitally produced } \\
\text { overlays for mixed-reality experiences }\end{array}$ \\
\hline Additive manufacturing & $\begin{array}{l}\text { Advances in additive manufacturing, using a widening range of materials } \\
\text { and methods. Innovations include 3D bioprinting of organic issues }\end{array}$ \\
\hline $\begin{array}{l}\text { Blockchain and } \\
\text { distributed ledger } \\
\text { technology }\end{array}$ & $\begin{array}{l}\text { Distributed ledger technology based on cryptographic systems that } \\
\text { manage, verify and publicly record transaction data; the basis of } \\
\text { "cryptocurrencies" such as bitcoin }\end{array}$ \\
\hline $\begin{array}{l}\text { Advanced materials and } \\
\text { nanomaterials }\end{array}$ & $\begin{array}{l}\text { Creation of new materials and nanostructures for the development of } \\
\text { beneficial material properties, such as thermoelectric efficiency, shape } \\
\text { retention and new functionality }\end{array}$ \\
\hline $\begin{array}{l}\text { Energy capture, storage } \\
\text { and transmission }\end{array}$ & $\begin{array}{l}\text { Breakthroughs in battery and fuel cell efficiency; renewable energy } \\
\text { through solar, wind, and tidal technologies; energy distribution through } \\
\text { smart grid systems; wireless energy transfer; and more }\end{array}$ \\
\hline $\begin{array}{l}\text { New computing } \\
\text { technologies }\end{array}$ & $\begin{array}{l}\text { New architectures for computing hardware, such as quantum computing, } \\
\text { biological computing or neural network processing, as well as innovative } \\
\text { expansion of current computing technologies }\end{array}$ \\
\hline Biotechnologies & $\begin{array}{l}\text { Innovations in genetic engineering, sequencing and therapeutics, as well } \\
\text { as biological computational interfaces and synthetic biology }\end{array}$ \\
\hline Geoengineering & $\begin{array}{l}\text { Technological intervention in planetary systems, typically to mitigate } \\
\text { effects of climate change by removing carbon dioxide or managing solar } \\
\text { radiation }\end{array}$ \\
\hline Neurotechnology & $\begin{array}{l}\text { Innovations such as smart drugs, neuroimaging and bioelectronic } \\
\text { interfaces that allow for reading, communicating and influencing human } \\
\text { brain activity }\end{array}$ \\
\hline Space technologies & $\begin{array}{l}\text { Developments allowing for greater access to and exploration of space, } \\
\text { including microsatellites, advanced telescopes, reusable rockets and } \\
\text { integrated rocket-jet engines }\end{array}$ \\
\hline
\end{tabular}

Source: (World Economic Forum, 2018a).

Rapid growth and diffusion of smart digital technologies will have a fundamental impact on the world economy that will have multifaceted nature and will affect all major macroeconomic variables - GDP, employment, investment, consumption, trade, inflation et al (Schwab, 2015).

The next five years will be transformational for enterprises, consumers, and governments. The Internet of Things (IOT) will boost the economy through the data and the bridging of the physical and digital worlds. Indeed, it is estimated that by the year 2023 (Allhoff and 
Henschke, 2018; Bittencourt et al., 2018; Lim, Kwon, and Lee, 2018; Lu, Papagiannidis, and Alamanos, 2018 Shelagh, 2018):

- only in the United States, the number of smart home devices will exceed \$ 1 billion (about $\$ 725$ for one family);

- about 6 million industrial robotic systems will be launched in the world and annual spending on manufacturing loT solutions will reach about $\$ 450$ billion;

- governments throughout the world will invest heavily in loT devices to stimulate the development of smart cities that will be equipped with smart cameras and street lamps, traffic control systems in real time, utilities usage, crime control, and environmental factors;

- annual investment in this sphere is expected to reach nearly $\$ 900$ billion.

Alec Ross notes that rapid development of the Internet of Things is being achieved through four main engines (Ross, 2017, p. 15):

1. the number of cars connected up to the Internet on the roads. It is expected that within the period from 2015 to 2020, it will grow from 23 to 152 million;

2. the dissemination of smart devices that are worn as a piece of clothing or jewelry - for only one year between 2013 and 2014 their number was doubled;

3. the implementation of "smart home" systems. According to the Juniper Research Report (2014), the revenues generated from "smart home" services had been set to reach a global market value of $\$ 71$ billion by 2018 ;

4. production. McKinsey Global Institute predicts that by 2025 only in the area of production the economic influence of the Internet of Things will have grown from $\$ 900$ billion to $\$ 2.3$ trillion per year.

Raymond Kurzweil predicts that there will be a merger between human intelligence and artificial intelligence in 2029 and Singularity will come in the year 2045. He defines the term "Singularity" as "a future period during which the pace of technological change will be so rapid, its impact so deep, that human life will be irreversibly transformed" (Kurzweil, 2005). Singularity is "an era in which our intelligence will become increasingly non biological and trillions of times more powerful than it is today" ... it "will enable us to transcend our biological limitations and amplify our creativity. In this new world, there will be no clear distinction between human and machine, real reality and virtual reality" (Kurzweil, 2005).

Raymond Kurzweil defined a number of principles in the concept of Singularity and explored them in the book (Kurzweil, 2005). The main reason for impending Singularity, in his view, is the Law of Accelerating Returns, the basic gist of which is in accelerating the pace of technological evolution. The development of almost all modern technologies goes at an explosive pace, exponentially. Exponential growth can start almost imperceptibly, and then quickly accelerate (Kurzweil, 2005).

New development models based on intangible component, smart technologies and data are seen as effective means of addressing the urgent challenges of sustainable development of countries, regions, and cities - economic, social and environmental problems. Working 
together in a better way to address the great challenges faced by humanity is one of the main priorities of the European Research Area. In fact, the ERA includes six priorities:

- building more effective national research systems;

- optimal transnational cooperation and competition (coopetition), including the creation of a high-quality, accessible research infrastructure;

- an open labour market for researchers;

- gender equality and gender mainstreaming in research;

- optimal circulation, access to and transfer of scientific knowledge, including through digital ERA, open access to scientific publications and data;

- international cooperation.

As noted in the ERA Progress Report 2016 (European Commission, 2017), cooperation between the EU Member States and Associated Countries with the aim of finding the best ways to solve modern challenges "is central to Europe's ability to respond to a dynamic and changing world."

Consequently, it is important to examine the perspectives of formation of scientificeducational and innovative spaces between the EU and Associated Countries considering also the features of the digital economy.

Priority attention of many scientists is given to the problem of cooperation in R\&D, education and innovation both at the country and firm levels, and among the countries. Indeed, the study (Gunther et al., 2017) focuses on the analysis of cross-border scientific cooperation between Germany and Poland. The role of transnational organizations in European innovation policy and of the policy networks established between these organizations and supranational institutions is investigated in the work (Grande and Peschke, 1999). The authors of the article (Tumelero, Sbragia and Evans, 2019) consider scientific cooperation between companies in the sphere of ecological innovations. Nevertheless, despite the significant contribution of scientific papers, existing approaches to European scientific-educational and innovative cooperation are limited to the EU Member States and do not consider prospects for engagement with Associated Countries such as Ukraine.

Therefore, the aim of the study is to identify opportunities and priorities of creating an interstate and cross-border scientific-educational and innovative spaces as a means of cooperation between Ukraine as Associated Country and the EU Member States taking into account the key priorities of the ERA and the major challenges of the digital economy in the conditions of Association Agreement between the EU and Ukraine.

\section{Methodology}

This study was conducted using the following methods: analysis and synthesis, abstracting and generalization, and systemic approach being considered as a strategic one to determine 
opportunities, and priorities in creating an interstate and cross-border European scientificeducational and innovative spaces.

Systemic approach implies accounting for the interactions among a number of items forming an integral whole (IGI Global. Disseminator of Knowledge, 2019). In terms of systemic approach, a research subject is a system, which has input (resources are transferred to the system and affect it), output (an end product of the system), its relationship to external environment and feedback (which is relevant for open systems). The system has also its internal structure - a set of interrelated elements that transform input resources into outputs and allow to achieve system goals.

\section{Results and Discussion}

In the new geopolitical reality, under the multiple challenges related to digital economy, the role of the driver in building "Europe of different speeds," could be played by Poland and Ukraine (in the post-war "old Europe" this function was performed by France and Germany) in order to use the "window of opportunity" that provides the transition from the 5 th to the 6th "long wave" of Kondratyev. The example of using this "window of opportunity" was demonstrated by the new industrial countries of South-East Asia which have become the socalled "Asian tigers" when moving from the 4th to the 5th "long wave" of Kondratyev. To achieve this, Poland and Ukraine have significant opportunities and competitive advantages:

- highly qualified and educated human capital (of 130 countries, Poland and Ukraine rank, respectively, 31st and 24th on the Global Human Capital Report 2017 (World Economic Forum, 2018b);

- advantageous geographical location - in the heart of Europe, at the intersection of major transport and trade routes;

- large consumer market unsaturated with individual commodities - the population of Poland and Ukraine is respectively 38,2 and 44,4 million people (World Economic Forum, 2018b);

- a well-developed network of academic institutions and universities that need to be connected to each other and to industry;

- the industrial capacity requiring large-scale innovation-based modernization to ensure high levels and quality of production.

Both countries are particularly interested in developing defense, energy, scientificeducational and innovative spaces. With a view to their formation, we have proposed to consider Ukrainian universities as a platform for undergraduate education from post-Soviet (Azerbaijan, Turkmenistan), Asian (China, Pakistan) and African (Nigeria) countries for Bachelor's degree and further education in Poland and other Member States of the EU for Master's degree (Liashenko \& Pidorycheva, 2017).

Actually, the necessary prerequisites for this scenario implementation are already in place many universities, scientific institutions, and social organizations of Ukraine have concluded relevant agreements with universities and innovative structures of European countries. For 
example, a Memorandum of cooperation between National Science-Technological Association of Ukraine, Uzhgorod National University and the Technical University of Košice was signed in March 2017 in Košice (Slovakia). In September 2016, similar memorandums of agreement were signed between Academy of Economic Sciences of Ukraine, Institute of Industrial Economics of the NAS of Ukraine, Poltava University of Economics and Trade and from the Polish side - Poznań University of Economics and Business, Higher Vocational School in Suwałki and Technology Park in Suwałki.

Establishment of a common Polish-Ukrainian scientific-educational space can be complemented with the entrepreneurial component. Namely, students who have entrepreneurial abilities and who are studying in Ukraine (on Bachelor's curriculum) start their own business in the business-incubator of the corresponding Ukrainian university and then, transfer it to the corresponding domestic scientific or industrial park. While continuing their education in Poland (for Master's degree), they adapt their small business to the relevant technology park in Poland, that makes them already residents of the EU. This allows them to enter the large Polish market as well as the Pan-European market, without losing ties with Ukraine.

In the process of the formation of interstate and cross-border scientific-educational and innovative spaces, the following challenges, that correspond to the priorities of ERA, can be solved:

- development of bilateral and multilateral relations in scientific-educational and innovative spheres in order to achieve maximum results from the convergence of national and regional economic interests, the creation of the necessary conditions for the market of innovative goods development and providing scientific-educational services;

- identification of mutual interest zones, allocating priority technology areas in them (including key emerging technologies of the fourth industrial revolution) for joint scientificeducational and innovative projects; creating favorable conditions for their implementation for the benefit of states and regions;

- development of human capital and staffing system of scientific-educational and innovative cooperation, professional training of managers and agents of innovative and scientific-educational programs and projects, among other things, in the sphere of the digital economy;

- effective use of all available scientific-educational and innovative infrastructure, its development;

- implementation of new mechanisms ensuring closer and more effective interaction between the states, scientific organizations, universities, and entrepreneurs;

- removing of possible legal and administrative barriers, creating of conditions for gradual harmonization of national systems of institutional and legal regulation of scientificeducational and innovative activity, standardization and product/services certification in the field of development and production of high-technology products/services, technical regulation and self-regulation. 
In building of Ukrainian-Polish scientific-educational and innovative spaces, the following inter-state priorities can be defined:

- institutional ensuring of the realization of interstate and cross-regional scientificeducational and innovative activities;

- increase of the innovative activity of enterprises in the production sector (Kwilinski, 2017; 2018a; 2018b; 2018c; 2018d; Yakubovskiy et al., 2017);

- introduction of economic and financial instruments and promotion of the regimes of innovative and entrepreneurial activities (Lakhno et al, 2018; Pająk et al., 2016);

- effective use of intellectual property, development of its common market;

- institutional transformation of the innovative sphere, namely, creating conditions to implement the concept of "Innovative lift: from school to Europe" (Liashenko \& Pidorycheva, 2017);

- personnel training and skills development in innovative and entrepreneurial spheres;

- creation of joint digital and physical platforms, complementary value chains, joint ventures and other forms of economic cooperation (Głowski and Kvilinski, 2017);

- introduction of measures in the field of export and customs.

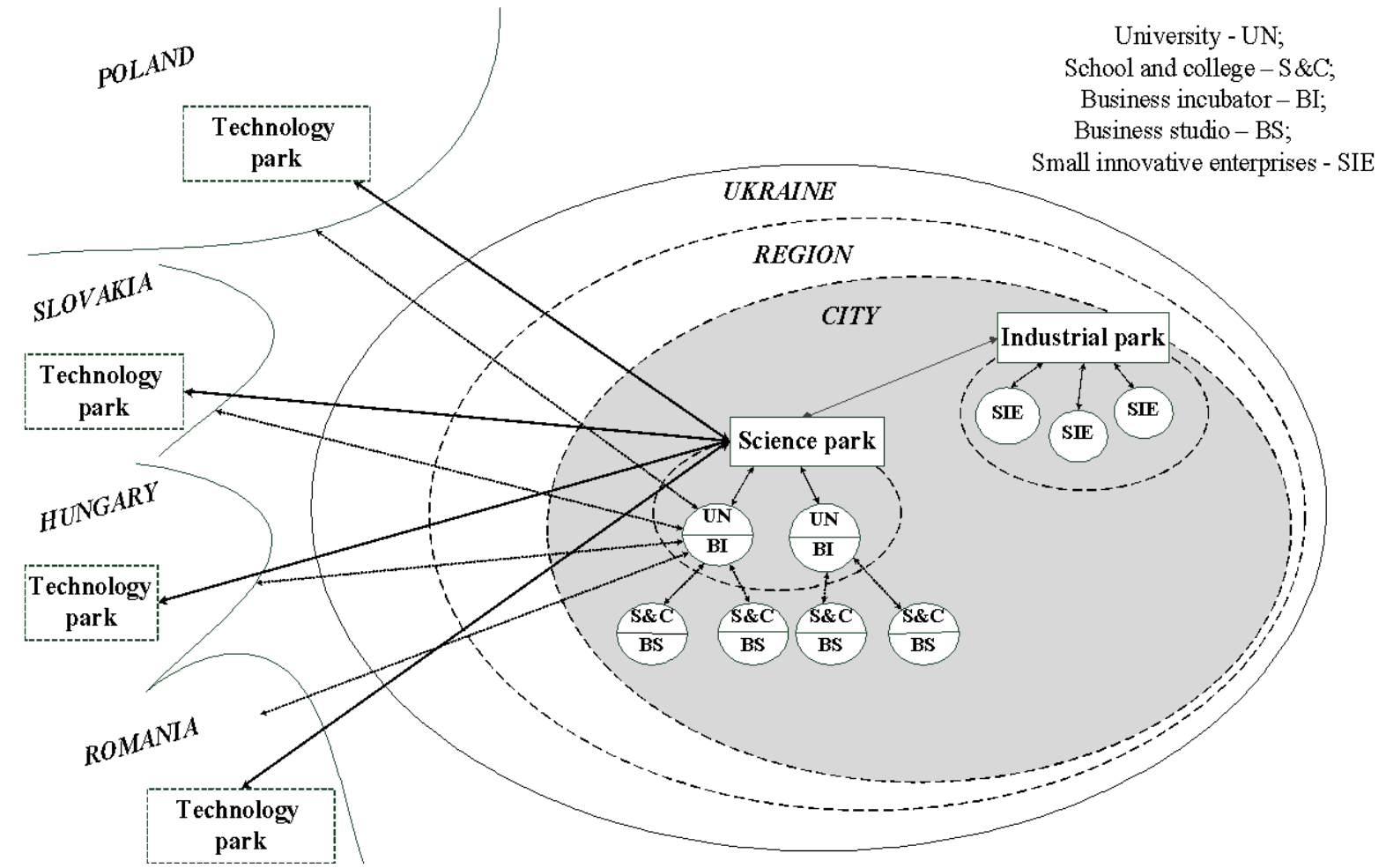

Figure 2. Scheme of cross-border high-technology cluster formation Source: own research.

Based on the interstate and cross-border scientific-educational and innovative spaces, interstate and cross-border innovative systems and high-tech clusters can be created in the future. Research suggests that as the first approximation can be proposed the main steps of cross-border nano- and biotechnologies clusters formation shown in Fig. 2: 
I. Choosing profiled institution of the National Academy of Sciences of Ukraine and establishing its branch in the relevant Ukrainian partner university.

II. Signing a cooperation agreement with a foreign partner university.

III. Providing equipment to structural units engaged in research in the field of high technology.

IV. Staffing, internships, academic exchanges.

V. Providing financing by attracting funds from the European, national and regional programmes, and structural funds, local business structures, through loans, grants and other sources not prohibited by law.

VI. Preparing proposals to devise national and regional "smart-specialization" strategies and to diversify traditional industries of regions and cities of partner countries.

VII. Introduction of new special courses "Economics and Entrepreneurship," "Nanotechnologies and Economics," "Biotechnologies and Economics" for physical and biological specialties at partner universities.

VIII. Providing services of business-incubators for small enterprises and replication of developments (nano- and biotechnologies) based on local incubators, science, technology and industrial parks.

One of the operating scientific center - Dnieper Scientific Center of the National Academy of Sciences of Ukraine and Ministry of Education and Science of Ukraine - can conduct an experiment on formation of Polish-Ukrainian scientific-educational and innovative space in the form of a pilot project of a cross-border high-tech cluster. Scientific and methodological support can be undertaken by the Institute of Industrial Economics of the NAS of Ukraine and its Dnipro department.

\section{Conclusions}

Many countries face serious problems emanating from the fast-growing impact of smart digital technologies to all areas of society. In addition, nowadays an active process of formation of bilateral and multilateral linkages in various fields of cooperation between countries is undertaken. This study seeks to consider the prospects of creating interstate and cross-border scientific-educational and innovative spaces between the EU Member States and Ukraine as Associated Country considering the major challenges of the digital economy and key priorities of the ERA within the context of Association Agreement between the EU and Ukraine. We rely on a systemic approach in order to propose the promising directions of cooperation between European countries towards the formation of the effective scientificeducational and innovative spaces.

Particular attention in this regard has been given to the creation of a common PolishUkrainian scientific-educational and entrepreneurial space; existing prerequisites and priorities of economic cooperation between countries are identified.

It has been proposed to form an interstate and cross-border nano- and biotechnology cluster as a cooperation tool between Ukraine and the EU Member States. Nanotechnology and 
biotechnology are smart digital technologies which in the ensuing years will lead to a radical transformation of global value chains, will be at the heart of research and development, the activities of business structures and government policies, which makes our proposals both relevant and perspective. These issues require further more in-depth interdisciplinary research. In particular, exploring how the formation of cross-border high-technology clusters will allow European countries to take advantage of digital technologies.

\section{References}

Allhoff, F., \& Henschke, A. (2018, September). The Internet of Things: Foundational ethical issues. Internet of Things, 1-2, 55-66. https://doi.org/10.1016/j.iot.2018.08.005

Bittencourt, L., Immich, R., Sakellariou, R., Fonseca, N., Madeira, E. Curado, M., Villas, L., DaSilva, L., Lee, C. \& Rana, O. (2018, October). The Internet of Things, Fog and Cloud continuum: Integration and challenges. Internet of Things, 3-4, 134-155. https://doi.org/10.1016/j.iot.2018.09.005

Cooke, P. (2001). Strategies for regional innovation systems: learning transfer and applications. Centre for advanced Studies Cardiff University. Retrieved from http://www.pacaonline.org/cop/docs/P Cooke Strategies for regional innovation systems.pdf

Dźwigoł, H., \& Dźwigoł-Barosz, M. (2018). Scientific research methodology in management sciences. Financial and Credit Activity: Problems of Theory and Practice, 2(25), 424-437. https://doi.org/10.18371/fcaptp.v2i25.136508

Dźwigoł, H., Aleinikova, O., Umanska, Y., Shmygol, N., \& Pushak, Y. (2019). An entrepreneurship model for assessing the investment attractiveness of regions. Journal of Entrepreneurship Education, 22(1), 1-7.

European Commission. (2017). European Research Area Progress Report 2016. Report from the commission to the council and the European parliament. URL: http://ec.europa.eu/research/era/pdf/era progress report2016/era progress report 2016 co $\underline{\text { m.pdf }}$

Głowski, P. \& Kvilinskyi, O. (Eds.). (2017). Economic Transformation in Ukraine: Comparative Analysis and European Experience. Warsaw, Poland: Consilium Sp. zo.o. Retrieved from https://instituteicd.org/wp-content/uploads/2016/07/Monografia Kvilinskyi.pdf

Goldberg, I., Goddard, J. G., Kuriakose, S., \& Racine, J.-L. (2011). Igniting Innovation: Rethinking the Role of Government in Emerging Europe and Central Asia. Retrieved from https://openknowledge.worldbank.org/handle/10986/2358

Grande, E. \& Peschke, A. (1999). Transnational cooperation and policy networks in European science policy-making. Research Policy, 28(1), 43-61. http://doi.org/10.1016/S0048-7333(98)00099-7

Gunther, J., Latifi, G., Lubacha-Sember, J., \& Tobelmann, D. (2017). Scientific Cooperation in a German-Polish Border Region in the Light of EU Enlargement. Foresight and STI Governance, 11(1), 42-53. http://doi.org/10.17323/2500-2597.2017.1.42.53

IGI Global. Disseminator of Knowledge. (2019). What is Systemic approach? Retrieved from https://www.igi-global.com/dictionary/systemic-approach/29095 
Juniper Research Report. (2014). Smart Home revenues to reach $\$ 71$ billion by 2018. Juniper Research Finds. Retrieved from https://www.juniperresearch.com/press-release/smart-home-pr1

Kurzweil, R. (2005). The singularity is near: when humans transcend biology. Retrieved from http://stargate.inf.elte.hu/ seci/fun/Kurzweil,\%20Ray\%20-\%20Singularity\%20ls\%20Near,\%20Th e\%20\%28hardback\%20ed\%29\%20\%5Bv1.3\%5D.pdf

Kwilinski, A. (2017). Development of industrial enterprise in the conditions of formation of information economics. Thai Science Review, Autumn 2017, 85-90. https://doi.org/10.5281/zenodo.1414236

Kwilinski, A. (2018a). Mechanism of modernization of industrial sphere of industrial enterprise in accordance with requirements of the information economy. Marketing and Management of Innovations, 4, 116-128. http://doi.org/10.21272/mmi.2018.4-11

Kwilinski, A. (2018b). Mechanism of formation of industrial enterprise development strategy in the information economy. Virtual Economics, 1(1), 7-25. https://doi.org/10.34021/ve.2018.01.01(1)

Kwilinski, A. (2018c). Mechanism for assessing the competitiveness of an industrial enterprise in the information economy. Research Papers in Economics and Finance, 3(1), 7-16. https://doi.org/10.18559/ref.2018.1.1

Kwilinski, A. (2018d). Trends of development of the informational economy of Ukraine in the context of ensuring the communicative component of industrial enterprises. Economics and Management, 1(77), 64-70.

Lakhno, V., Malyukov, V., Bochulia, T., Hipters, Z., Kwilinski, A., \& Tomashevska, O. (2018). Model of managing of the procedure of mutual financial investing in information technologies and smart city systems. International Journal of Civil Engineering and Technology, 9(8), 1802-1812. Retrieved from http://www.iaeme.com/MasterAdmin/UploadFolder/IJCIET_09_08_181/IJCIET_ 09_08_181.pdf

Liashenko, V., \& Pidorycheva, I. (2017). Rehionalni naukovi tsentry NAN Ukrainy ta MON Ukrainy yak yadro rozbudovy rehionalnykh innovatsiinykh system $v$ umovakh detsentralizatsii [Regional science centers under NAS and MES of Ukraine as the core of the development of regional innovation systems in the context of decentralization]. Economic Herald of the Donbas, 1(47), 1320 [in Ukrainian].

Lim, S., Kwon, O., \& Lee, D. H. (2018, October). Technology convergence in the Internet of Things (IoT) startup ecosystem: A network analysis. Telematics and Informatics, 35(7), 1887-1899. https://doi.org/10.1016/j.tele.2018.06.002

Lu, Y., Papagiannidis, S., \& Alamanos, E. (2018, November). Internet of Things: A systematic review of the business literature from the user and organisational perspectives. Technological Forecasting and Social Change, 136, 285-297. https://doi.org/10.1016/j.techfore.2018.01.022

Pająk, K., Kamińska, B., \& Kvilinskyi, O. (2016). Modern trends of financial sector development under the virtual regionalization conditions. Financial and credit activity: problems of theory and practice, 2(21), 204-217. https://doi.org/10.18371/fcaptp.v2i21.91052

Ross, A. (2017). The Industries of the Future. New York City: Simon \& Schuster Ltd. 
Schwab, K. (2015). The Fourth Industrial Revolution. Geneva, Switzerland: World Economic Forum. Retrieved from https://luminariaz.files.wordpress.com/2017/11/the-fourth-industrial-revolution2016-21.pdf

Shelagh, D. (2018, July 19). How the Internet of Things will transform consumerism, enterprises, and governments over the next five years. Business Insider. Retrieved from https://www.businessinsider.com/iot-forecast-book-2018-7

The Organization for Economic Co-operation and Development. (2013). OECD Reviews of Regional Innovation. Regions and Innovation: Collaborating across Borders. Paris: OECD Publishing. Retrieved from https://doi.org/10.1787/19976585

Tumelero, C., Sbragia, R. \& Evans, S. (2019). Cooperation in R \& D and eco-innovations: The role in companies' socioeconomic performance. Journal of Cleaner Production, 207, 10 January 2019, 1138-1149. https://doi.org/10.1016/j.jclepro.2018.09.146

World Economic Forum. (2018a). The Readiness for the Future of Production Report 2018. Retrieved from http://www3.weforum.org/docs/FOP Readiness Report 2018.pdf

World Economic Forum. (2018b). The Global Human Capital Report 2017. Preparing people for the future of work. Retrieved from https://weforum.ent.box.com/s/dari4dktg4jt2g9xo2o5pksj patvawdb

Yakubovskiy, M., Liashenko, V., Kamińska, B., \& Kvilinskyi, O. (2017). Economy modernization of industrial regions (based on the example of Ukraine). In P. Głowski and O. Kvilinskyi (Eds.), Economic Transformation in Ukraine: Comparative Analysis and European Experience (pp. 12-29). Warsaw, Poland: Consilium Sp. z o.o. Retrieved from https://institute-icd.org/wpcontent/uploads/2016/07/Monografia Kvilinskyi.pdf 